of scholars on the American shore. He was an activist and an institution builder who thought that democratic politics was too important to be left to governments.

Professor Girard will be remembered in the United States in particular for his passionate attention to transatlantic relations. Much like Raymond Aron and JeanBaptiste Duroselle of an earlier era, Michel Girard cared about Europe and North America. Displaying institutional leadership as well as insight, Michel Girard left political science and the world of politics a better place because of his extraordinary initiative and intellectual vision.

Charles Doran Johns Hopkins University, School of Advanced International Studies

\section{LEROY HARDY}

Leroy C. Hardy, emeritus professor of political science at California State University, Long Beach (CSULB), passed away on November 2, 2008, at the age of 81 . He specialized in California government and politics and was best known as a long-term consultant to state legislators on the subject of the reapportionment of legislative districts.

Professor Hardy taught full time in the CSULB Political Science Department from February 1953 until his retirement in 1986; after which he taught on a part-time basis until the early 1990s. He chaired the department from 1980 to 1984 . After leaving the department, he taught in the CSULB Senior University until shortly before his death. Teaching was his first priority, and he was a popular teacher.

Born in Oklahoma and raised in Southern California, Professor Hardy received his BA degree from the University of California, Santa Barbara, in 1949, and his Ph.D. from UCLA in 1955. While still a UCLA graduate student working on the reapportionment of legislative districts, he was appointed in 1951 to the research staff of the Republican-controlled State Reapportionment Committee, and his contribution was so widely admired that he was called upon again in 1961 by the Democratic-controlled California legislature. He participated as well in census-induced redistricting in the early 1970 s and 1980 s, and in the special redistricting forced by the U.S. Supreme Court's decision in the mid-196os mandating one man, one vote.
Professor Hardy's ability to work with both parties on reapportionment issues reflected the integrity and responsibility of his approach to those issues. It also reflected enormous attention to detail, especially in his earliest work before the advent of computers, when reapportionment work was extremely time consuming and laborious. Careers of federal and state legislators depended upon this work.

From his vantage point as a reapportionment expert, Professor Hardy aspired to make reapportionment of legislative districts something other than an exercise favoring political incumbents. At first he believed that government would be more disinterested if a city or community were served by several legislators rather than being incorporated into one district.

Subsequently, following heavily politicized (gerrymandered) redistricting in California in the early 1980s, which he criticized, Professor Hardy helped develop an elaborate bottom-up, community-based, and non-partisan reapportionment concept establishing very small but permanent binding units of redistricting to insulate reapportionment from politics as much as possible. These building-block units, which were implemented in state redistricting in Arizona, were designed to be aggregated into compact legislative districts that would respect county and city boundaries. They were designed to make reapportionment immune from incumbent manipulation, and thereby to make party politics more competitive.

Hardy worked to develop the community-based concept, while serving as a senior research associate at the Rose Institute at Claremont McKenna College, where he collaborated on a series of writings, including Reapportionment Politics (1981), which he edited with Alan Heslop and Stuart Anderson, and Redistricting in the 1980's: A 50-State Survey (1993) with Alan Heslop and George S. Blair. Hardy also wrote two texts for students, California Government (Canfield Press, 4th ed., 1973), and, with Robert Morlan, Politics of California (Dickenson Publishing Co., 1968).

Barry H. Steiner, California State University, Long Beach

\section{WILLIAM V. MOORE}

On April 25, 2009, the College of Charleston and the Charleston community lost a beloved teacher, mentor, scholar, and col- league, William V. Moore, distinguished professor of political science.

In his 37 year career at the college, Dr. Moore was, first and foremost, a truly devoted teacher and mentor. He held many different titles and undertook many responsibilities over the span of his career, but he always identified himself as a teacher. His courses were invariably the first to reach capacity; one of the most persistent tasks for the chair of the department was explaining to students that there simply were no more seats available in Dr. Moore's class. He always had an extremely large number of advisees and took on special responsibilities for student-athletes, always mindful of the special challenges posed by pursuing both athletic and academic achievement.

A caring father and family man, Bill, balanced the life of a teacher with an impressive scholarly output, a passionate commitment to College of Charleston athletics, and a willingness to share his expertise with both print and television journalists in Charleston and across the country. He was as much the voice of the political science department as he was the voice of Cougar basketball.

Bill earned his BA and masters degrees from Southern Illinois University and his Ph.D. from Tulane. He was a well-known expert on South Carolina politics, Southern politics, and political extremism. He was the author of Political Extremism in the United States, co-author of South Carolina Politics and Government, as well as numerous scholarly articles, encyclopedia entries, and publications on Southern and extremist politics, civil rights, electoral politics, campaign spending, and intergovernmental relations. He served as chair of the department of political science, director of the master of public administration program, speaker of the faculty, director of summer programs, director of the Taft Institute for high school civics teachers, NCAA faculty representative, and vice president and president of the Southern Conference. In 1997, Bill was designated as the S.C. Governor's Professor of the Year. He has also been awarded the distinguished teaching award at the college (1981), as well as the distinguished service award (2000), the distinguished advising award (2001), and the first-ever distinguished teacher-scholar award (2001). Bill also served on the Board of Advisors at the Charleston School of Law. 